\title{
IMPLEMENTASI MODEL COOPERAT IF LEARNING PADA PEMBELAJARAN MATEMATIKA UNTUK MENINGKATKAN RESILIENSI MATEMATIS DAN HASIL BELAJAR SISWA KELAS XI SMA N 2 BANTUL
}

\author{
Widayati $^{a}$, Y. Rini Prastuti ${ }^{b}$

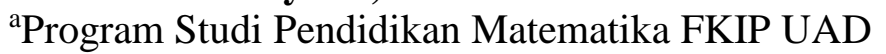 \\ Jl. Ringroad Selatan, Tamanan, Banguntapan, Bantul, Yogyakarta. \\ widayati@pmat.uad.ac.id \\ ${ }^{\mathrm{b}}$ SMA Negeri 2 Bantul \\ Jl. RA Kartini, Nogosari, Trirenggo, Bantul, DIY.
}

\begin{abstract}
ABSTRAK
Penelitian ini dilakukan dengan tujuan untuk meningkatkan Resiliensi Matematis dan Hasil Belajar menggunakan Model Cooperatif Learning siswa kelas XI SMA Negeri 2 Bantul Tahun Ajaran 2017/2018. Dikarenakan adanya beberapa siswa kurang antusias ketika pembelajaran matematika, kurangnya keyakinan akan kemampuan pemahaman materi. Adapun metode penelitian Penelitian ini menggunakan jenis metode Penelitian Tindakan Kelas (PTK) atau dikenal dengan Classroom Action Research, dan dilaksanakan dalam 2 siklus. Tahapan setiap siklus yaitu: (1) perencanaan, (2) pelaksanaan, (3) pengamatan, dan (4) refleksi. Penelitian tindakan kelas ini dilaksanakan secara kolaboratif partisipatif antara peneliti dengan guru Matematika Kelas XI MIPA 3 dan dilaksanakan pada semester ganjil Tahun Pelajaran 2017/2018. Subjek penelitian tindakan kelas ini adalah siswa kelas XI MIPA 3 SMA Negeri 2 Bantul dengan jumlah siswa 29. Teknik pengumpulan data menggunakan teknik non tes dan teknik tes. Alat Pengumpul data menggunakan lembar observasi, angket dan tes formatif. Data yang diperoleh dianalisis menggunakan teknik analisis kualitatif dan analisis kuantitatif. Pada siklus I rata-rata dari hasil observasi selama proses pembelajaran matematika menggunakan model Cooperatif Learning diperoleh 67,13\% kategori cukup sedangkan pada siklus II sebesar 73,2 \% kategori baik. Keaktifan siswa dalam mengikuti pembelajaran mengalami kenaikan yang lebih baik. Dari hasil Angket tentang Resiliensi pada siklus I dengan rata-rata 65,04 dengan kategori cukup dan siklus II sebesar 70,11 dengan Baik. Siswa antusias dalam mengikuti pembelajaran, banyak siswa berusaha untuk bisa menyelesaikan tugas. Hasil tes siklus I diperoleh nilai rata-rata 67,73 dan nilai rata-rata siklus II adalah 76,67 , mengalami kenaikan. Sebagian besar siswa mampu menyelesaikan soal, hanya beberapa siswa kurang lengkap dalam menjawabnya.
\end{abstract}

Kata kunci : Cooperatif Learning, Resiliensi, Hasil Belajar.

\begin{abstract}
This research was conducted with the aim of increasing Mathematical Resilience and Learning Outcomes using the Cooperative Learning Model of class XI Bantul 2 High School 2013/2014 Academic Year. Due to the presence of several students who were less
\end{abstract}


enthusiastic when learning mathematics, lack of confidence in the ability to understand material.

The research method of this research uses the Classroom Action Research method, known as Classroom Action Research, and carried out in 2 cycles. The stages of each cycle are: (1) planning, (2) implementation, (3) observation, and (4) reflection. This classroom action research is carried out in a participatory collaborative manner between researchers and Mathematics Teachers of Class XI MIPA 3 and is held in the odd semester of the 2017/2018 Academic Year. The subject of this class action research was students of class XI MIPA 3 Bantul State High School 2 with the number of students 29. Data collection techniques used non-test techniques and test techniques. Data collection tool using observation sheets, questionnaires and formative tests. The data obtained were analyzed using qualitative analysis techniques and quantitative analysis. In the first cycle the average of the results of the observation during the learning process of mathematics using Cooperative Learning models obtained $67.13 \%$ sufficient categories while in the second cycle it was $73.2 \%$ in the good category. The activity of students in participating in learning experiences a better increase. From the results of the Questionnaire about Resilience in the first cycle with an average of 65.04 with sufficient categories and the second cycle of 70.11 well. Students are enthusiastic in participating in learning, many students try to be able to complete the task. Cycle I test results obtained an average value of 67.73 and the average value of the second cycle was 76.67, increasing. Most students are able to solve questions, only a few students are incomplete in answering.

Keywords: Cooperative Learning, Resilience, Learning Outcomes.

\section{Pendahuluan}

Matematika merupakan salah satu mata pelajaran pada sekolah Menengah yang masih dianggap sulit bagi siswa. Hal ini dapat bisa disebabkan dari cara penyampaian guru, model pembelajaran yang digunakan. Matematika merupakan ilmu yang sifatnya abstrak. Untuk menyelesaikan masalah matematika, seorang peserta didik harus sering berlatih, belajar dengan berpikir dan bernalar. Seperti yang dikemukakan Sukardjono (2007:13) menyatakan bahwa "matematika adalah cara/metode berpikir dan bernalar." Menurut Kementerian Pendidikan dan Kebudayaan (Kemdikbud, 2013:iii), "Matematika adalah bahasa universal untuk menyajikan gagasan atau pengetahuan secara formal dan presisi sehingga tidak memungkinkan terjadinya multi tafsir, penyampaiannya adalah dengan membawa gagasan dan pengetahuan konkret ke bentuk abstrak melalui pendefisian variabel dan parameter sesuai dengan yang ingin disajikan, penyajian dalam bentuk abstrak melalui matematika akan 
mempermudah analisis dan evaluasi selanjutnya".

Matematika merupakan ilmu yang mendasari ilmu-ilmu lain, oleh karenanya setiap anak harus menguasai ilmu tersebut. Banyak siswa yang tidak suka belajar matematika, karena menurut mereka matematika sulit difahami, banyak rumus yang harus diingat. Oleh karenanya perlu adanya model pembelajaran yang membuat siswa termotivasi untuk belajar Matematika. Pembelajaran merupakan suatu interaksi antara siswa dan guru untuk mencapai tujuan yang sama. Menurut Muhammad Surya dalam Isjoni (2010:72-73), pembelajaran merupakan suatu proses perubahan yang dilakukan individu untuk memperoleh suatu perubahan perilaku yang baru secara keseluruhan, sebagai hasil dan pengalaman individu itu sendiri dalam interaksi dan lingkungannya. Pembelajaran merupakan akitivitas siswa dan guru. Pembelajaran yang menjadikan siswa aktif yakni model Cooperatif Learning yang sudah mulai dibiasakan digunakan dalam proses pembelajaran matematika.
Cooperatif Learning adalah pembelajaran yang berfokus pada pemanfaatan kelompok kecil siswa untuk berdiskusi, bekerja sama dalam memaksimalkan kondisi belajar untuk mencapai tujuan yang sama. Hal ini sesuai pendapat Sunal dan Hans dalam Isjoni (2009:15) mengemukakan bahwa Cooperatif Learning merupakan suatu cara pendekatan atau serangkaian strategi yang khusus dirancang untuk memberi dorongan kepada siswa agar bekerja sama selama proses pembelajaran. Selanjutnya Stahl dalam Isjoni (2009: 15) menyatakan pembelajaran kooperatif dapat meningkatkan belajar siswa lebih baik dan meningkatkan sikap saling tolong-menolong dalam perilaku sosial. Begitu juga dari hasil penelitian Putri Nurmadinah (2014:170) bahwa penerapan model pembelajaran kooperatif dapat meningkatkan pemahaman siswa pada materi luas daerah segitiga di Kelas VII MTs Negeri Palu Selatan. Adapun beberapa tujuan dari model Cooperatif Learning, yakni: meningkatkan keaktifan siswa dalam menyelesaikan tugas-tugas akademik, 
agar antar siswa terbiasakan menerima perbedaan pendapat, mengembangkan kepedulian pada teman maupun lingkungan, meningkatkan prestasi belajar siswa, saling berbagi dalam memahami konsep-konsep yang sulit, memotivasi siswa agar senang belajar matematika. Ada banyak keuntungan dari penerapan model pembelajaran kooperatif, antara lain:

a. Meningkatkan kepekaan serta kepedulian social.

b. Antar siswa dapat saling belajar mengenai perilaku sosial, tukar informasi.

c. Menumbuhkan sifat suka berbagi dan suka menolong.

d. Membangun persahabatan yang dapat berlanjut hingga dewasa.

e. Meningkatkan saling percaya kepada sesama manusia.

f. Meningkatkan kesediaan menggunakan ide orang lain yang dirasakan lebih baik.

g. Meningkatkan kegemaran berteman tanpa memandang perbedaan kemampuan, jenis kelamin, normal atau cacat yang dirasakan lebih baik.
Dari hasil observasi dan wawancara dengan guru Matematika di SMA N 2 Bantul, beberapa siswa terlihat kurang antusias megikuti pelajaran, beberapa siswa ada yang kurang aktif ketika guru memberi tugas. Siswa membutuhkan model atau metode yang menarik untuk meningkatkan dan memperbaiki cara belajar matematika agar semua siswa aktif mengikuti pelajaran dan tidak bosan. Oleh karenanya diperlukan model Cooperatif Learning, agar siswa lebih bersemangat dan aktif mengikuti pembelajaran Matematika. Dalam model Cooperatif Learning, belajar siswa dengan cara dikelompokkan, kemudian berdiskusi, dilanjutkan mempresentasikan hasil diskusi.

Banyak siswa di SMA Negeri

2 Bantul yang aktif berusaha menyelesaikan tugas, banyak siswa juga yang kurang yakin dengan penyelesaian soal yang sudah dikerjakan. Sebagian saja siswa yang mau mempresentasikan hasil pekerjaannya. Oleh karenanya dapat dikatakan bahwa resiliensi siswa masih kurang. Beberapa siswa yang tidak segera menyelesaikan soal 
karena merasa kesulitan, hal ini terjadi terutama pada siswa putra. Siswa yang memiliki resiliensi matematis akan selalu berusaha bisa menyelesaikan tugas, memiliki kemampuan untuk menumbuhkan kepercayaan dirinya.

Resiliensi matematik merupakan sikap siswa yang berkualitas dalam pembelajaran matematika yang meliputi: percaya diri melalui usaha keras akan keberhasilan, memperlihatkan ketekunan ketika menemui kesulitan dalam memahami konsep, mempunyai keinginan untuk bertanya jika tidak faham, keinginan untuk berbagi dengan teman yang lain, melakukan penelitian. Resiliensi adalah kemampuan seseorang untuk menilai, mengatasi, dan meningkatkan diri ataupun mengubah dirinya dari keterpurukan atau kesengsaraan dalam hidup, karena setiap orang itu pasti mengalami kesulitan ataupun sebuah masalah dan tidak ada seseorang yang hidup di dunia tanpa suatu masalah ataupun kesulitan (Grotberg, E.1995). Oleh karenanya siswa dalam belajar matematika diperlukan resiliensi matematik. Johnston-Wilder, S. \& Lee, C. (2008, 2010a) berpendapat bahwa resiliensi matematis adalah sebuah konsep penting dalam pendidikan, karena masih banyak siswa mengalami kesulitan dan kegagalan dalam mempelajari matematika. Siswa yang memiliki resiliensi matematis mempunyai kemampuan untuk menumbuhkan kepercayaan dirinya bahwa dia mampu mempelajari matematika. Siswa yang mempunyai resiliensi matematik yang baik menganggap bahwa matematika itu bukan merupakan hambatan, bahkan ketika siswa itu sendiri mengalami kesulitan, dia akan mempertahankan kepercayaan dirinya sampai berakhir sukses. Dia akan senang membantu teman/kelompoknya berdasarkan pengetahuan serta pemahaman yang dimilikinya dan dapat memanfaatkan bantuan dan dukungan temannya apabila diperlukan. Pakar lainnya, Yeager \& Dweck (2012) mendefinisikan resiliensi sebagai "perilaku, atribusi (suatu unsur dari proses persepsi yang bisa sangat mempengaruhi sikap/tingkah laku seseorang), atau respons emosional 
terhadap tantangan akademis atau sosial yang positif atau bermanfaat untuk pembangunan. Adanya resiliensi disebabkan karena adanya beberapa hambatan yang dihadapi yang diikuti dengan hasil yang kurang. Dalam konteks matematika, hambatan tersebut dapat berupa gagal dalam mengelola kelas, berjuang melampaui toleransi, kebosanan, rasa malu karena kinerja buruk, kurikulum atau instruksi berkualitas rendah, dan adanya interaksi guru-siswa atau antara siswa dengan siswa yang kurang baik. Kooken, J. Welsh, M.E., Mccoach, D.B., Johnson-Wilder, S and Lee (Sumarmo, 2015) mengkonsepkan resiliensi matematik sebagai sikap positif terhadap matematika yang memberi kesempatan siswa tetap melanjutkan belajar matematika meski menghadapi kesulitan. Menurut (Johnston-Wilder, S., 2013), berdasarkan teori yang dikemukakan oleh Johnston-Wilder, S. \& Lee, C. (2010b) terdapat empat faktor yang berkorelasi dengan resiliensi, yaitu:
(1) Value: Keyakinan bahwa matematika adalah ilmu yang harus dipelajari dan banyak manfaatnya.

(2) Struggle: Pengakuan bahwa perjuangan dalam mempelajari matematika bersifat universal bahkan dengan orang-orang yang memiliki kemampuan matematika tingkat tinggi;

(3) Growth: Keyakinan bahwa semua orang dapat mengembangkan keterampilan matematika.

(4) Resillience: Orientasi terhadap situasi atau kesulitan negatif dalam pembelajaran matematika yang menghasilkan respons positif. Faktor pertama, value, Chouinard, R. \& Roy, N. (2007) berpendapat dalam konteks prestasi akademik, teori ini mengemukakan bahwa siswa akan lebih tertarik dan lebih termotivasi untuk belajar matematika jika mereka percaya itu berharga. Dalam konteks ini, keberhasilan dalam belajar ditentukan oleh persepsi siswa tentang pentingnya matematika bagi kehidupan dan dunia mereka. Semakin berharga dan percaya diri siswa dalam memahami matematika, semakin besar motivasi untuk mempelajarinya, dan semakin besar 
kemungkinan mereka bertahan serta berusaha dalam menghadapi kesulitan.

Menurut Kooken, J. Welsh, M.E., Mccoach, D.B., JohnsonWilder, S and Lee (Sumarmo, 2015) mengkonsepkan resiliensi matematik sebagai sikap positif terhadap matematika yang memberi kesempatan siswa tetap melanjutkan belajar matematika meski menghadapi kesulitan. Dalam pembelajaran Cooperatif Learning, siswa melakukan diskusi, ada beban mental jika tidak ikut mengerjakan tugas, siswa presentasi dari hasil diskusi, dengan demikian pada diri siswa ada keinginan untuk bisa menyelesaikan tugas, walaupun sulit, siswa dituntut untuk aktif dalam diskusi, siswa dibiasakan mengeluarkan pendapat, siswa juga belajar presentasi di depan kelas. Oleh karena itu dengan model Cooperatif Learning diharapkan dapat meningkatkan resiliensi matematik siswa.

Berdasarkan latar belakang dan kajian teori peneliti melakukan penelitian dengan tujuan :
1. Untuk meningkatkan Resiliensi Matematis menggunakan Model Cooperatif Learning siswa kelas XI SMA N 2 Bantul Tahun Ajaran 21017/2018.

2. Untuk meningkatkan Hasil Belajar Matematika menggunakan Model Cooperatif Learning siswa kelas XI SMA N 2 Bantul Tahun Ajaran 2107/2018.

\section{Metode Penelitian}

Penelitian ini menggunakan jenis metode Penelitian Tindakan Kelas (PTK) atau dikenal dengan Classroom Action Research, dan dilaksanakan dalam 2 siklus. Tahapan setiap siklus yaitu: (1) perencanaan, (2) pelaksanaan, (3) pengamatan, dan (4) refleksi (Arikunto, 2007: 16). Penelitian tindakan kelas ini dilaksanakan secara kolaboratif partisipatif antara peneliti dengan guru Matematika Kelas XI MIPA 3 dan dilaksanakan pada semester ganjil Tahun Pelajaran 2017/2018. Subjek penelitian tindakan kelas ini adalah siswa kelas XI MIPA 3 SMA Negeri 2 Bantul dengan jumlah siswa 29 orang yang terdiri dari 8 orang 
siswa laki-laki dan 21 orang siswa perempuan. Teknik pengumpulan data menggunakan teknik non tes dan teknik tes. Alat Pengumpul data menggunakan lembar observasi dan tes formatif. Lembar observasi digunakan untuk mengamati kinerja guru, dan aktivitas siswa, sedangkan tes formatif digunakan untuk mengetahui hasil belajar kognitif siswa. Data yang diperoleh dianalisis menggunakan teknik analisis kualitatif dan analisis kuantitatif.

Tabel 1. Penentuan Skor

\section{Klasifikasi Observasi}

$\begin{array}{ll}\text { Persentase } & \text { Taraf } \\ \text { Keberhasilan } & \text { Keberhasilan } \\ \text { Tindakan } & \end{array}$

$\begin{array}{ll}85 \%-100 \% & \text { Sangat Baik } \\ 70 \%-85 \% & \text { Baik } \\ 65 \%-70 \% & \text { Cukup } \\ 50 \%-65 \% & \text { Kurang } \\ 0 \%-50 \% & \text { Sangat Kurang }\end{array}$

Untuk menghing tingkat kemajuan siswa satu kelas pada suatu pembelajaran, maka perlu dicari rata - rata untuk membuat kesimpulan atas hasil penelitian dengan menggunakan rumus :

$$
\bar{X}=\frac{\sum_{i=1}^{N} x_{i}}{N}
$$

$\sum_{i=1}^{N} x_{i}=$ Jumlah nilai semua siswa

$$
N=\text { Banyak siswa }
$$

Indikator Keberhasilan

Keberhasilan penelitian tindakan kelas ditandai dengan adanya perubahan kearah perbaikan baik mengenai resiliensi maupun hasil belajarnya. Adanya peningkatan hasil belajar mahasiswa, minimal mencapai nilai cukup.

\section{Hasil Dan Pembahasan}

Penelitian dilaksanakan pada semester Ganjil Tahun Ajaran 2017/2018. Observasi dilaksanakan bulan Agustus 2018. Penelitian ini terdiri dari 2 siklus, setiap siklus ada 2 pertemuan. Pelaksanaan penelitian dalam satu minggu dilaksanakan sebanyak satu kali, hal ini disesuaikan dengan jadwal mata pelajaran Matematika pada Peminatan Matematika, kelas XI MIPA 3 yaitu pada hari Kamis jam ke 3,4.

$$
\text { Pelaksanaan Penelitian }
$$
Tindakan Kelas pada siklus I, siklus II meliputi empat tahapan yaitu perecanaan, pelaksanaan tindakan, observasi, dan refleksi. 
Untuk mengetahui peningkatan resiliensi siswa, peneliti menggunakan observasi dan angket resiliensi yang diberikan saat akhir siklus I dan akhir siklus II. Itu dilakukan agar peneliti mengetahui seberapa besar peningkatan resiliensi yang dilakukan siswa.

$$
\text { Pada pelaksanaan }
$$
pembelajaran dilaksanakan dua kali dan satu kali tes. Setiap pertemuan berlangsung selama 2x45 menit. Adapun rincian dalam pelaksanaan penelitian : Awal pertemuan guru menjelaskan tentang Silabus dan RPP dengan materi Persamaan Trigonometri. Guru menjelaskan model Cooperatif Learning sambil memberi motivasi kepada siswa, sehingga rata-rata siswa menunjukkan antusiasnya pada mata pelajaran ini. Guru menjelaskan pentingnya memahami konsep, seperti yang dinyatakan Zulkardi (2003:7) bahwa mata pelajaran matematika menekankan pada konsep. Setiap siswa diharapkan berusaha menyimak serta memahami materi yang didapatkan dari penjelasan guru., apabila sudah faham kemud ian mengerjakan soal latihan yang ada pada LKM. Selanjutnya hasil dari diskusi, dipresentasikan didepan kelas, siswa lainnya memperhatikan.

Hasil observasi yang dilakukan guru dan observer pada pembelajaran matematika menggunakan model Cooperatif Learning, serta hasil penyebaran Lembar Angket tentang resiliensi matematis siswa pada siklus 1 dan siklus II, dapat dilihat pada tabel berikut. 
Tabel 2. Hasil observasi aktivitas siswa dalam model Cooperatif Learning serta resiliensi matematis kelas XI C SMA N 2 Bantul

\section{No Indikator}

1. Sikap tekun, percaya diri dan bekerja keras

2. Bersosialisasi, mudah memberi berdiskusi

3. Memunculkan ide, mencari solusi

4. Memotivasi diri

5. Menunjukkan rasa ingin tahu

6. Memiliki kemampuan mengontrol diri Rata-rata

\section{Siklus I Siklus II}

$70,7 \% \quad 75,8 \%$

bantuan, $65,5 \% \quad 68,9 \%$

$63,8 \% \quad 72,35 \%$

$75,8 \% \quad 79,3 \%$

$65 \% \quad 68,9 \%$

$62 \% \quad 74 \%$

$67,13 \% \quad 73,2 \%$

Hal ini dapat kita lihat dari hasil analisis pada pada Tabel berikut :

\section{Tabel 3. Hasil Analisis Lembar Angket Resiliensi Siklus I dan siklus II}

No Indikator

1. Sikap tekun, percaya diri dan bekerja keras

2. Bersosialisasi, mudah memberi bantuan, berdiskusi

3. Memunculkan ide, mencari solusi

4. Memotivasi diri

5. Menunjukkan rasa ingin tahu

6. Memiliki kemampuan mengontrol diri

Rata-rata
Persentase

Siklus I

$65,28 \%$

$62,8 \%$

$64,74 \%$

$74,07 \%$

$62,96 \%$

$60,44 \%$

$65,04 \%$
Persentase

Siklus II

$68,2 \%$

$64,74 \%$

$78,37 \%$

$74,26 \%$

$61,8 \%$

$73,33 \%$

70,11
Dari hasil observasi dan angket terdapat perbedaan, hal ini karena untuk observasi hanya diamati dari proses pembelajaran menggunakan model Cooperatif Learning dan resiliensi,yang dilihat observer saja, sedangkan pada angket masih ada tambahan pernyataan yang tidak bisa dengan hanya diamati.

Implementasi ... (Widayati)
Selama proses pembelajaran matematika menggunakan Cooperatif Learning dengan cara berdiskusi dan presentasi, banyak siswa yang aktif berdiskusi, berusaha menyelesaikan soal dari Lembar Kerja Siswa (LKS), terdapat beberapa siswa yang bertanya pada teman sekelompok jika ada soal yang belum difahami. 
Setelah diskusi selesai beberapa siswa mulai presentasi, mereka bersemangat untuk dapat menyelesaikan soal matematika serta bersemangat untuk dapat presentasi di depan kelas.

Dilihat dari resiliensi matematiknya, banyak siswa yang bersemangat dalam belajar, hal ini bisa dilihat ketika guru menjelaskan materi maupun contoh soal, banyak siswa yang memperhatikan, dan tidak segan untuk bertanya kepada guru maupun temannya apabila ada yang belum difahami. Setiap kelompok berusaha menyelesaikan soal dengan diskusi, ada juga yang berusaha mengerjakan sendiri. Siswa langsung mempresentasikan hasil diskusi apabila yakin bahwa jawabannya benar, sementara yang kurang yakin akan bertanya dengan guru baru kemudian mempresentasikan didepan kelas. Terdapat beberapa siswa kurang berminat menyelesaikan 234

siswa yang mempunyai kemampuan lebih dengan senang hati memberi penjelasan pada temannya yang belum faham. Banyak siswa yang berusaha dapat memahami serta menyelesaikan soal, mereka merasa nyaman belajar dengan berdiskusi. Ada juga siswa mempunyai penyelesaian yang berbeda ketika mengerjakan identitas trigonometri. Mereka saling berdiskusi dan tidak merasa terganggu apabila ada temannya yang bertanya. Dari hasil observasi dan angket pada siklus I dan siklus II menunjukkan adanya peningkatan resiliensi matematik.

Tabel 4. Hasil analisis Tes Siklus I dan II

Hasil Tes Siklus I Siklus

$\begin{array}{lll}\text { Nilai } & & \text { II } \\ \text { Tertinggi } & 96 & 91 \\ \begin{array}{l}\text { Nilai } \\ \text { Terendah }\end{array} & 52 & 48 \\ \text { Rata-rata } & 67,73 & 76,67\end{array}$

Pada siklus I dengan siklus II ada penurunan nilai tertinggi dan nilai terendah, tetapi rata-rata nilai meningkat, artinya di siklus II banyak siswa yang mendapatkan nilai semakin baik. Terdapat sebagian

ISSN: 2088-687X menyelesaikan tugas yang diberikan guru, terutama siswa laki-laki.

Kesalahan yang dilakukan siswa dalam menyelesaiakan soal antara 
lain, pada soal membuktikan identitas, $1-\frac{\cos ^{2} x}{1+\sin x}=\sin x$ Ada kesalahan ketika angka 1 dipindah ruas kanan, pada pemberian tanda positif atau negatif.

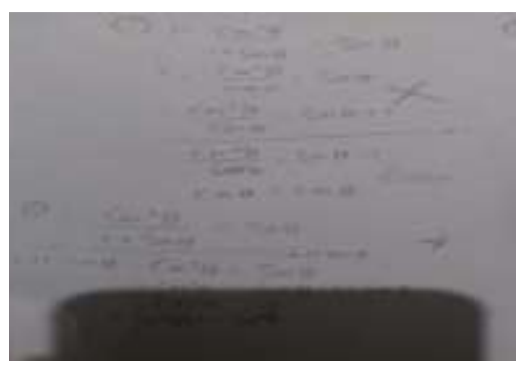

Gambar 1. Hasil Pekerjaan Siswa I

Beberapa siswa tidak selesai dalam menyelesaikan soal, nampak ragu-ragu dalam menjawab,

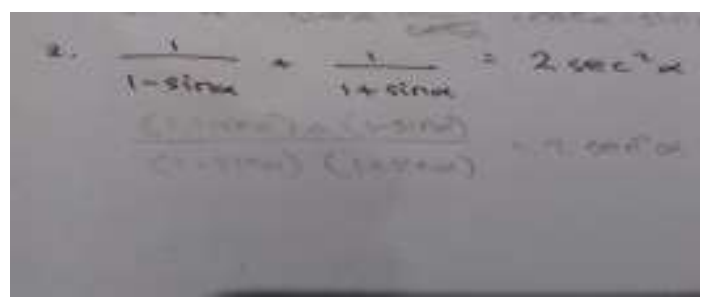

Gambar 2. Hasil Pekerjaan Siswa II

Sedangkan pada soal menentukan himpunan penyelesaian dari $\cos x=\frac{\sqrt{3}}{2}$ untuk $0 \leq x \leq 2 \pi$. Ada siswa yang masih salah dalam menentukan besaran sudut.

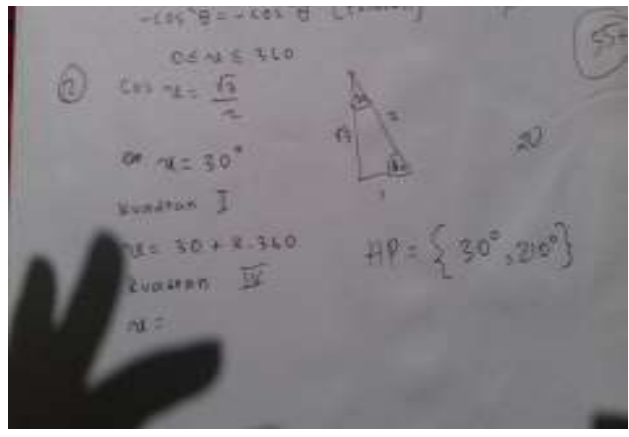

Gambar 3. Hasil Pekerjaan Siswa III

Banyak juga yang hasil akhirnya tidak dijadikan radian, hal ini menjadikan nilai berkurang.

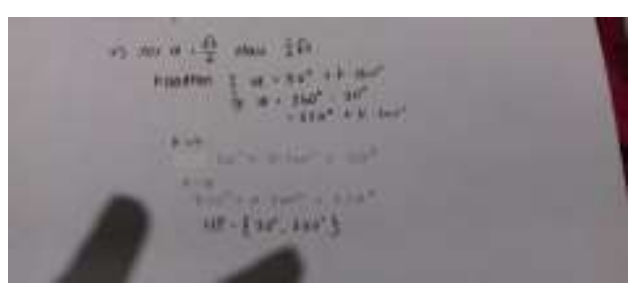

Gambar 3. Hasil Pekerjaan Siswa

IV

Pada siklus I terdapat beberapa kesalahan menjawab yang dilakukan siswa dikarenakan ketika dijelaskan oleh guru, beberapa siswa kurang serius memperhatikan dan kurang sungguh-sungguh dalam belajar sehingga jawabannya kurang lengkap.

Pada siklus II, guru berusaha memahamkan materi maupun penyelesaian soal yang dirasa sulit difahami siswa dalam penyelesaian dalam persamaan Trigonometri, yaitu ketika menentukan kuadran yang 
memenuhi persamaan tersebut. Walaupun guru dalam setiap pertemuan selalu memotivasi, masih ada juga siswa yang belajarnya kurang sungguh-sungguh. Dilihat dari selama proses pembelajaran yang bisa dilihat dari hasil observasi hasilnya cukup baik, bahkan setiap pertemuan hampir semua kelompok bisa presentasi yang dilakukan siswa secara bergantian. Oleh karenanya dengan model Cooperatif Learning pada pembelajaran matematika siswa kelas XI dapat meningkatkan hasil belajar.

\section{Simpulan}

Berdasarkan penelitian yang sudah dilakukan serta dari pembahasan yang sudah diuraikan diatas, dapat disimpulkan bahwa pembelajaran matematika menggunakan model Cooperatif Learning dapat meningkatkan resiliensi matematik siswa dan hasil belajar siswa kelas XI IPA C SMA N 2 Bantul. Hal tersebut ditunjukkan dengan data berikut.

1. Pada siklus I rata-rata dari hasil observasi selama proses pembelajaran matematika menggunakan model Cooperatif
Learning diperoleh 67,13\% kategori cukup sedangkan pada siklus II sebesar 73,2 \% kategori baik. Keaktifan siswa dalam mengikuti pembelajaran mengalami kenaikan yang lebih baik.

2. Dari hasil Angket Resiliensi pada siklus I dengan rata-rata 65,04 dengan kategori cukup dan siklus II sebesar 70,11 dengan Baik. Siswa antusias dalam mengikuti pembelajaran, banyak siswa berusaha untuk bisa menyelesaikan tugas.

3. Dari hasil tes siklus I diperoleh nilai rata-rata 67,73 dan nilai rata-rata siklus II adalah 76,67, mengalami kenaikan. Sebagian besar siswa mampu menyelesaikan soal, hanya beberapa siswa kurang lengkap dalam menjawabnya. 


\section{Pustaka}

Arikunto, Suharsimi. 2007. Penelitian Tindakan Kelas. Jakarta : Bumi Aksara

Chouinard, R. \& Roy, N. (2007). Relations among competence beliefs, utility value, achievement goals, and effort in mathematics. British Journal of Educational Psychology, 77, 501-517.

Depdikbud. 2014. Permendikbud Nomor 59 Tahun 2014 Pasal 1 Ayat 2. Jakarta : Depdikbud.

Grotberg, E. (1995). A Guide to Promoting Resilience in Children: Strengthening The Human Spirit. Benard Van Leer Fondation.

Isjoni. (2009). Cooperative Learning Mengembangkan Kemampuan Belajar Berkelompok. Bandung : Alfabeta.

Isjoni. 2011. Cooperative Learning. Bandung : Alfabeta

Johnston-Wilder, S., \& Lee, C. $\left(2010^{a}\right)$. Developing Mathematical Resilience. BERA Annual Conference 2010, University of Warwick, 1-4 September 2010.

Johnston-Wilder, S. \& Lee, C. $\left(2010^{b}\right) . \quad$ Mathematical resilience. Mathematics Teaching, 218, 38-41. $\begin{array}{rrr}\begin{array}{c}\text { Johnston-Wilder, } \\ \text { Measuring }\end{array} & \text { S. } & \text { (2013) } \\ \text { mathematical }\end{array}$ resilience : an application of the construct of resilience to the study of mathematics. In: AERA 2013, San Francisco, California, 27 Apr-1 May 2013 (Submitted).

Putri Madinah, 2014. Penerapan Model Pembelajaran Kooperatif Untuk Meningkatkan Pemahaman Siswa Pada Materi Luas Daerah Segitiga Di Kelas VII Mts Negeri Palu Selatan, AKSIOMA Jurnal Pendidikan Matematika, Volum 03 Nomor 02, September 2014.

Slavin, Robert. 2015. Cooperative Leraning. Bandung : Nusa Indah.

Sukardjono. 2007. Hakikat dan Sejarah Matematika.Jakarta : Universitas Terbuka

Sumarmo, U. (2015). Resiliensi Matematik. [Online]. Tersedia: http://utarisumarmo. dosen.stkipsiliwangi.ac.id/m ateri/resiliansimatematikmathematicalresilience/.

Yeager, D. \& Dweck, C. (2012). Mindsets That Promote Resilience: When Students Believe That Personal Characteristics Can Be Developed. Educational Psychologist, 47, 302-314.

Zulkardi. 2003. "Pendidikan Matematika di Indonesia: Beberapa Permasalahan dan 
ISSN: 2088-687X

Upaya Penyelesaiannya.”

Palembang: Unsri. 
